\title{
MODEL PENGEMBANGAN STRATEGI PEMASARAN BERBASIS TEKNOLOGI INFORMASI DALAM MENINGKATKAN DAYA SAING UMKM DI JEPARA
}

\author{
Sisno Riyoko ${ }^{1}$ Budi Lofian ${ }^{1}$ \\ ${ }^{I}$ Fakultas Sains dan Technology, Univeristas Islam Nahdlatul Ulama Jepara \\ Email :sisno@unisnu.ac.id
}

\begin{abstract}
This study wanted to produce a model for developing marketing strategy based on Information Technology (IT) is a form of marketing strategy development model by taking into account and utilize Information Technology. The purpose of this study was to better efficiency at enhancing the competitiveness of SMEs through the use of Information Technology. Micro, Small and Medium cultivated IT base is expected will be increased competitiveness. Objective: 1) undescrebed conditions of SMEs that have used information technology. 2) completion of a development model of ITbased marketing strategies that can be applied practically. 3) application models empirically, and 4) unprovable floating model application of ITbased marketing strategy. To achieve these objectives do action research approach, is research activities continued with implementation. Therefore, the model-based marketing strategy information technology into solutions for marketing problems of SMEs and increasing competitiveness.
\end{abstract}

Keywords : Marketing strategy; SMEs, information technology; competitivennes.

\begin{abstract}
Abstrak: Penelitian ini ingin menghasilkan model untuk mengembangkan strategi pemasaran berbasis Teknologi Informasi (TI) adalah bentuk model pengembangan strategi pemasaran dengan memperhatikan dan memanfaatkan Teknologi Informasi. Tujuan dari penelitian ini adalah untuk efisiensi yang lebih baik dalam meningkatkan daya saing UMKM melalui penggunaan Teknologi Informasi. Basis IT Mikro, Kecil dan Menengah diharapkan akan meningkatkan daya saing. Tujuan: 1) kondisi UMKM yang belum digunakan yang telah menggunakan teknologi informasi. 2) penyelesaian model pengembangan strategi pemasaran berbasis TI yang dapat diterapkan secara praktis. 3) model aplikasi secara empiris, dan 4) aplikasi model mengambang berbasis strategi pemasaran berbasis TI. Untuk mencapai tujuan tersebut dilakukan pendekatan penelitian tindakan, adalah kegiatan penelitian dilanjutkan dengan implementasi.. Oleh karena itu, model strategi pemasaran berbasis teknologi informasi menjadi solusi untuk masalah pemasaran UMKM dan meningkatkan daya saing.
\end{abstract}

Keywords : Strategi pemasaran, tekbologi informasi, daya saing, UMKM. 


\section{PENDAHULUAN}

Usaha Mikro Kecil dan Menengah (UMKM) memiliki peran yang sangat penting dalam mendorong tumbuhnya ekonomi di Indonesia. Beberapa penelitian yang telah dilakukan ternyata Usaha Mikro Kecil dan Menengah memiliki peran dalan memperkokoh perekonomian nasional melalui berbagai keterkaitan usaha seperti fungsi pemasok, fungsi produksi, fungsi penyalur dan pemasar bagi hasil produk-produk industri besar. Disamping itu Usaha Mikro Kecil dan Menengah juga dapat meningkatkan efisiensi ekonomi khususnya menyerap tenaga kerja lokal dan dapat meningkatkan sumber daya manusia untuk menjadi wiraswasta-wiraswasta yang tangguh.

Di pihak lain keberadaan Usaha Mikro Kecil dan Menengah tenyata sulit beradaptasi dengan struktur pasar yang ada. Usaha Mikro Kecil dan Menengah pada umumnya kurang memiliki informasi pasar sebagai akibat keterbatasan kemampuan yang dimilikinya, sehingga ruang gerak Usaha Mikro Kecil dan Menengah secara ekonomi tetap lemah dan terbatas.

Keberadaan UMKM yang kuat ternyata telah menjadi sumber kekuatan ekonomi Negara maju, misalnya Jepang, Taiwan dan Korea Selatan. Di Jepang keberadaan UMKM-nya diakui telah memperkokoh perekonoian Jepang dan membawanya menjadi Negara industri. Semuanya itu tidak lepas dari kemampuan UMKM itu sendiri dalam menghadapi kondisi perekonomian yang semakin ketat. Salah satu kunci utama untuk dapat menghadapi kondisi ekonomi global adalah kemampuan daya saing. Kondisi UMKM yang daya saingnya masih rendah akan tersisih dalam persaingan, sehingga UMKM perlu meningkatkan daya saingnya.

Di Negara-negara Eropa khususnya Eropa Barat keberadaan UMKM sangat penting. Di Belanda misalnya, jumlah UMKM sekitar 95\% dari jumlah perusahaan di Negara kincir angin tersebut (Bijmolt dan Zirort, 2004), seperti Amerika Serikat, juga di negara industri maju lainnya yang tergabung dalam OEC seperti Jepang, Jerman, Perancis dan Kanada. Usaha Mikro Kecil dan Menengah merupakan motor penting dari pertumbuhan ekonomi dan progress teknologi (Tambun, 2006)

Di Negara sedang berkembang di Asia, Afrika dan Amerika Latin, UMKM juga berperan sangat penting khususnya dari perspektif kesempatan kerja, sumber pendapatan bagi kelompok miskin, distributor, pendapatan dan pengurangan kemiskinan dan pembangunan ekonomi pedesaan.

Studi tentang UMKM sebenarnya telah sering dilakukan karena hampir semua pihak dan kalangan sudah memiliki pemahaman yang sama tentang pentingnya peranan UMKM di masyarakat (Tambun et al, 2006). Usaha Mikro Kecil dan Menengah memiliki peranan dalam hal penyerapan tenaga kerja, penyumbang APBN pada skala nasional dan APBD atau PAD pada skala regional dan lokal. Hampir semua aspek yang berkaitan dengan perkembangan UMKM telah diteliti, misalnya aspek permodalan, kegiatan produksi dan eksportnya serta peningkatan kapasitas sumber daya manusianya. Dengan demikian peran informasi pemasaran menjadi isu sentral dan strategis untuk diteliti.

Studi tentang strategi pemasaran berbasis teknologi informasi bagi Usaha Mikro Kecil dan menengah dalam meningkatkan daya saing belum banyak dilakukan oleh para peneliti. Menurut M Tajudin, Abdul Manan dan Ahmad adil (2011) menghasilkan kesimpulan bahwa faktor yang melandasi UMKM terdorong menggunakan ecommerce terdiri dari 6 faktor yaitu dapat mengakses pasar global, mempromosikan produk, membangun merek, mendekatan dengan pelanggan, membantu komunikasi lebih cepat dengan pelanggan dan memuaskan pelanggan.

Oleh karena itu dalam penelitian ini ingin mencoba mengembangkan penelitian yang sudah ada tersebut dengan membuat model pengembangan strategi pemasaran usaha mikro kecil dan menengah berbasis teknologi informasi diharapkan dapat membantu Usaha Mikro Kecil dan Menengah (UMKM) dalam meningkatkan daya saing. Adapun tujuan dari penelitian ini adalah untuk melakukan identifikasi keberadaan Usaha Mikro Kecil dan Menengah dalam memanfaatkan teknologi informasi untuk kegiatan usahanya serta merumuskan dan menyusun model pengembangan strategi pemasaran berbasis Teknologi Informasi sebagai upaya dalam meningkatkan daya saing UMKM di Jepara.

\section{TINJAUAN PUSTAKA}

\section{Strategi Pemasaran}

Kegiatan pemasaran merupakan kegiatan yang memiliki cakupan yang sangat luas meliputi cakupan internal maupun cakupan ekternal perusahaan. Kotler (2006) mengemukakan bahwa pemasaran adalah proses sosial dan manajerial dimana individu atau kelompok bertujuan untuk memenuhi kebutuhan dan keinginannya melalui kreativitas penawaran dan pertukaran nilai produk dengan yang lain. Hal ini menunjukan bahwa pemasaran membutuhkan strategi yang diungkapkan dalam rencana-rencana yang realistis 
yang dihubungkan dengan kemungkinan memperoleh keuntungan.

Strategi bisnis dan keunggulan bersaing harus menjadi pedoman dalam pengembangan strategi pemasaran. Para pengambil keputusan harus dilibatkan dalam proses perencanaan bisnis meliputi : 1) peran serta dalam analisis dan perencanaan strategik perusahaan, 2) melayani manajer lain sebagai anggota tim perencanaan strategik unit bisnis dan 3) mengembangkan dan melaksanakan rencana pemasaran strategik untuk pasar yang dilayani perusahaan. craven, (2007)

Analisis situasi pemasaran merupakan identifikasi peluang pemasaran sebagai dasar untuk perancangan strategi pemasaran. Strategi pemasaran mencakup penargetan pasar dan analisis penempatan, pemilihan strategi pemasaran dan pengembangan serta penempatan produk. Strategi pasar sasaran mengidentifikasikan bagaimana suatu usaha menghubungkan pasar dengan produk. Untuk memilih pasar sasaran perlu dipertimbangkan daya tarik segmen dan sumber daya kekuatan bisnis perusahaan dalam suatu segmen. Keputusan pasar produk merupakan "focal point" dari suatu strategi pemasaran karena pentargetan pasar sebagai dasar untuk penempatan tujuan dan pengembangan strategi penempatan (Cravens, 2007).

Pengelolaan strategi pemasaran harus memperhatikan perancangan organisasi pemasaran yang efektif, pelaksanaan dan pengendalian strategi serta pemakaian sistim informasi untuk perencanaan dan manajemen dari stategi pemasaran. Dengan demikian strategi pemasaran merupakan prinsip yang menyeluruh untuk mencapai tujuan-tujuan pemasaran dan bisnis yang mencakup keputusan-keputusan bauran pemasaran dan aplikasi pemasaran. Menurut Kotler (2007) membagi strategi pemasaran menjadi tiga bagian yaitu 1) strategi pasar sasaran dan strategi pengembangan produk, 2) bauran pemasaran dan anggaran pemasaran serta 3) strategi pemasaran yang menyeluruh meliputi tujuan dan sasaran penjualan, pangsa pasar dan keuntungan.

Strategi pemasaran UMKM diarahkan untuk memenangkan persaingan di suatu pasar sasaran. Suatu persaingan akan dimenangkan jika strategi pemasaran produsen mampu menciptakan strategi bersaing (competitive strategy) yang mempunyai keunggulan bersaing. Menurut Porter (2007) strategi bersaing merupakan kombinasi antara tujuan yang diperjuangkan perusahaan dengan kebijakan yang digunakan untuk mencapai tujuan tersebut atau pencarian posisi yang menguntungkan dalam suatu industry sebagai tempat persaingan. Ada dua factor yang perlu dipertimbangkan dalam memilih strtaegi bersaing yaitu daya tarik suatu industry untuk memberikan laba jangka panjang dan penentuan posisi relative dalam suatu industri.

\section{Strategi Pemasaran Berbasis Teknologi Informasi}

Teknologi informasi mempunyai lima peran utama yaitu meningkatakan efisiensi, efektivitas, komunikasi, kolaborasi dan competitive. Disamping itu teknologi infomasi dapat digunakan untuk pengolahan transaksi atau transaction processing system (TPS) yang bertujuan untuk menggantikan pengolahan transaksi yang dilakukan manusia dengan teknologi informasi. Aplikasi teknologi infomasi ini menyediakan informasi bagi pengambil keputusan dalam suatu organisasi bisnis. Agar pengambilan keputusan lebih efektif diperlukan dukungan sumber data yang terintegrasi hingga membentuk suatu sistim informasi pendukung dalam pengambilan suatu keputusan (Yogiyanto, 2004)

Dilain pihak teknologi informasi dapat digunakan untuk media perdagangan yang disebut dengan perdagangan melalui internet khususnya dengan teknologi Web. Ada lima keuntungan menggunakan ecomerse di internet yaitu bisnis dapat dilakukan lebih cepat dan efektif, mengurangi kebutuhan modal kerja lebih hemat, lebih menjaga hubungan baik dengan pelanggan,dan memungkinkan sekali dalam menjalankan perdagangan (Kotler, 2004).

Penggunaan internet dalam bisnis sangat memungkinkan perusahaan dapat mengekploitasi peluang peluang pemasaran mengenai pelanggan dan calon pelanggan potensial. Oleh karena itu penggunaan e-comerse dalam perdagangan memiliki keunggulan baik untuk konsumen maupun untuk dunia bisnis yaitu kenyamanan, penghematan, pilihan atau seleksi personalisasi informasi (Martin, 2007). Lebih lanjut dikatakan adanya e-commerce perusahaan dapat meningkatkan layanan dengan melakukan interaksi yang lebih personal, dapat memberikan informasi sesuai dengan apa yang diinginkan oleh konsumen (Ghosh, 2008)

Menurut Hill (2010) keunggulan teknologi melalui penggunaan e-commerce akan memberikan manfaat dalam proses bisnis yaitu akan mempermudah perusahaan untuk memasuki pasar yang baru dan juga memperjelas kelemahan pasar dari perusahaan yang ada serta dapat menciptakan peluang, strategi baru, menyediakan peluang jasa pelanggan yang subtansial.

Pemasaran berbasis teknologi informasi dapat dikatakan sebagai pemasarasan yang memanfaatkan teknologi seperti internet. Menurut Needle yang dikutip Whiteley(2000) perdagangan 
memalui internet tidak selalu sesuai dengan semua produk atau semua orang. Internet sebagai media pemasaran dan saluran penjualan dapat diuji dengan hal-hal sebagai berikut:

1. Produk

Beberapa produk dapat dijual dengan melalui intenet. Penggunaan existing mail order memberikan indikasi dan produk teknikal yang disampaikan kepada pemakai internet dapat ditambahkan pada daftar.

2. Harga

Dalam intenet penjual tidak membutuhkan took retail dan fasilitas-fasilitas penjualan, sehingga relative lebih murah.

\section{Promosi}

Internet memberikan cara yang lebih mudah untuk mempromosikan produk. Promosi dalam internet tidak seperti bentuk pengiklanan yang lainnya, pelanggan mempunyai akses internet dan menggunakannya untuk menemukan produk yang dipromosikan.

4. Tempat.

Pembelian melalui internet dapat dikirimkan kepada pelanggan. Pelayanan informasi dapat dikirimkan secara elektronik, namun untuk produk dibutuhkan biaya pengiriman secara fisik.

\section{METODE PENELITIAN}

\section{Sampel}

Sampel dalam penelitian ini adalah responden atau UMKM yang bertempat tinggal di Jepara dengan karakteristik pria dan wanita. Adapun jumlah sampel dalam penelitian ini adalah 100 responden. Sedangkan teknik sampling yang digunakan dalam penelitian ini adalah purposive sampling yaitu sampel yang diambil berdasarkan karakteristik yang dibutuhkan dalam penelitian ini.

\section{Jenis dan sumber data}

Data yang dipakai dalam penelitian ini terdiri dari data primer dan data skunder. Data primer mengacu pada informasi yang dipereleh dari tangan pertama oleh peneliti yang berkaitan dengan variabel minat untuk tujuan spesifik studi (sekaran, 2006). Sedangkan data skunder diperoleh melalui tangan kedua yaitu dari Dinas Perindustrian dan daftar pustaka.

\section{Metode Pengumpulan data}

Metode pengumpulan data yang digunakan dalam penelitian tahun pertama maupun tahun kedua kuesiner dan Fokused Group Discution. Kuesioner merupakan suatu mekanisme pengumpulan data dengan memberikan daftar pertanyaan kepada responden. Sedangkan Fokused Group Discution (FGD) merupakan teknik pengumpulan data yang bertujuan menemukan makna sebuah tema menurut pemahaman sebuah kelompok. Teknik ini digunakan untuk mengungkap pemaknaan dari suatu kelompok berdasarkan hasil diskusi yang terpusat pada suatu permasalahan tertentu.

\section{HASIL DAN PEMBAHASAN}

\section{Identifikasi Profil UMKM}

Pada tahapan awal analisis model pengembangan strategi pemasaran berbasis teknologi informasi adalah melakukan identifikasi profil UMKM yang dalam melakukan kegiatan usahanya. Proses wawancara dan Fokus Group Discution (FGD) dilakukan untuk memperoleh hasil tersebut. Berikut ini adalah rangkuman identifikasi profil UMKM dari hasl wawancara dan FGD.

Tabel 1. Profil responden

\begin{tabular}{lll}
\hline Bahan Baku & Jumlah & Persentase \\
\hline Lokal & 60 & 60 \\
\hline Antar Pulau & 28 & 28 \\
\hline Luar & 12 & 12 \\
\hline Daerah pemasaran & & \\
\hline Daerah sekitar & 60 & 60 \\
\hline Antar pulau & 25 & 25 \\
\hline eksport & 15 & 15 \\
\hline Aset per tahun & & \\
\hline $501-1$ milyar & 4 & 4 \\
\hline $100-500$ juta & 22 & 22 \\
\hline$<100$ juta & 74 & 74 \\
\hline Jumlah Pegawai & & \\
\hline$>10$ orang & 41 & 41 \\
\hline $6-10$ orang & 22 & 22 \\
\hline$<5$ orang & 37 & 37 \\
\hline $\begin{array}{l}\text { Tingkat pendidikan } \\
\text { pegawai }\end{array}$ & \\
\hline Sarjana & 2 & 2 \\
\hline SMA & 30 & 30 \\
\hline SMP & 48 & 48 \\
\hline SD & 20 & 20 \\
\hline Sumber : & & \\
\hline
\end{tabular}

Sumber : hasil pengolahan data survey, 2016

Hasil pengolahan data menunjukan bahwa secara keseluruhan terdapat 100 responden yang berhasil ditemukan dan diamati yang tersebar di wilayah kecamatan Jepara kota, kecamatan tahunan, kecamatan pecangaan, kecamatan mayong dan kecamatan welahan. Dari 100 UMKM tersebut dapat diidentifikasi dalam memperoleh bahan baku 
untuk membuat produknya yaitu 60 responden $(60 \%)$ bahan baku berasal dari lokal daerah setempat, sebanyak 28 responden $(28, \%)$ berasal dari antar pulau dan 12 responden (12\%) bahan baku berasal dari luar negeri. Dengan demikian dapat disimpulkan bahwa bahan baku untuk membuat produk masih menggunakan bahan lokal, sehingga dari sisi biaya dapat dihemat.

Usaha Mikro Kecil dan Menengah yang ada di Jepara dalam memasarkan produknya sebanyak 60 responden $(60 \%)$ dipasarkan pada daerah lokal atau daerah sekitar, 25 responden $(25 \%)$ produk UMKM di pasarkan ke luar pulau dan hanya 15 responden $(15 \%)$ yang dipasrkan pada pasar luar negeri atau ekspor. Dengan demikian dapat disimpulkan bahwa daerah pemasaran produk UMKM masih terbatas pada pasar lokal. Oleh karena itu perlu model strategi pemasaran yang berbasis teknologi informasi.

Hasil penyebaran kusioner dan wawancara kepada 100 UMKM di Jepara menunjukan bahwa jumlah kekayaan yang dimilki pada saat penelitian ini dilakukan sebagai berikut : sebanyak 74 responden (74\%) memiliki kekayaan dibawah 100 juta. Sedangkan yang memiliki kekayaan antara 100 - 500 juta sebanyak 22 responden (22\%) dan sisanya yang memilki kekayaan $501-1$ milyar sebanyak 4 responden (4\%).

Berdasarkan hasil wawancara dan penyebaran kuesioner yang telah dilakukan terhadap 100 UMKM di Jepara diperoleh data tentang jumlah pegawai yang bekerja. Dari 100 UMKM tersebut sebanyak 37 responden (37\%) menyatakan jumlah pegawai kurang dari 5 orang, sebanyak 22 responden (22\%) memiliki jumlah 610 orang, sedangkan sisianya yaitu sebanyak 41 responden $(41 \%)$ memiliki jumlah pegawai sebanyak lebih dari 10 orang. Dengan demikian jumlah pegawai rata-rata lebih dari 10 orang.

Berdasarkan hasil penyebaran kuesioner dan wawancara terhadap 100 UMKM yang ada diperoleh informasi tentang tingkat pendidikan pegawai. Dari 100 responden 2 responden (2\%) pendidikan pegawai adalah sarjana, 30 responden (30\%) pendidikan Sekolah Menengah Atas, 48 responden $(48 \%)$ berpendidikan SMP dan sisanya sebanyak 20 responden (20\%) berpendidikan SD. Dengan demikian dapat disimpulkan bahwa pendidikan para pegawai yang bekerja di UMKM sebagian besar berpendidikan SMP. Oleh karena itu diperlukan tambahan ketrampilan dan pendidikan khusus.

\section{Identifikasi Kebutuhan Teknologi Informasi}

Tahapan penelitian berikutnya adalah melakukan identifikasi kebutuhan teknologi informasi dalam rangka perumusan model strategi pemasaran berbasis teknologi informasi. Data diperoleh melalui wawancara dan fokus group discution. Hasil tersebut dapat di rangkum dalam tabel berikut

Tabel 2. Identifikasi kebutuhan teknologi informasi

\begin{tabular}{lll}
\hline Kepemilikan komputer & Jumlah & Persentase \\
\hline Tidak memiliki & 55 & 55 \\
\hline Memiliki & 45 & 45 \\
\hline Program komputer & & \\
\hline Tidak memiliki & 55 & 55 \\
\hline Memiliki & 45 & 45 \\
\hline Pemasran online & & \\
\hline Pernah & 55 & 55 \\
\hline Tidak pernah & 45 & 45 \\
\hline Teknologi informasi & & \\
\hline Perlu & 75 & 75 \\
\hline Belum perlu & 25 & 25 \\
\hline Sumber
\end{tabular}

Sumber : hasil pengolahan data, 2016

Hasil pengolahan data yang telah dilakukan menunjukan bahwa secara keseluruhan terdapat 100 UMKM yang tersebar di sentra-sentra UMKM di Jepara. Dari 100 Usaha tersebut yang berhasil ditemui dan diwawancarai, sebanyak 55 UMKM (55\%) tidak memiliki computer dan sisanya sebanyak 45 UMKM (45\%) memiliki masingmasing 1 komputer. Kondisi ini menunjukan bahwa kemajuan teknologi informasi (computer) masih belum menyentuh UMKM. Keberadaan teknologi informasi belum banyak dimafaatkan oleh UMKM untuk kegiatan usahanya. Oleh karena itu diperlukan penerapan penggunaan dan sosialisasi pentingnya teknologi informasi untuk kegiatan usaha.

Hasil survey di lapangan menunjukan bahwa 55 UMKM (55\%) tidak memiliki program computer, 45 UMKM (45\%) memilki program computer. Namun computer yang dimiliki hanya dipakai untuk mendukung administrasi yang sederhana saja dan belum dimanfaatkan secara maksimal untuk mendukung keseluruhan kegiatan manajerial. Dengan demikian menunjukan bahwa kondisi UMKM di Jepara belum mampu memanfaatkan teknologi informasi untuk kegiatan bisnisnya.

Berdasarkan hasil pengolahan data yang telah dilakukan bahwa pengenalan kegiatan pemasaran secara online telah dipahami sebagian UMKM. Hal ini dapat dilihat bahwa dari 100 UMKM yang menjadi obyek penelitian menunjukan bahwa 55 UMKM (55\%) pernah melakukan kegiatan pemasaran secara online, dan sisanya sebanyak 45 UMKM (45\%) tidak pernah melakukan kegiatan pemasaran secara online. Kalau dilihat dari kepemilikan computer masih 
sedikit, sehingga pemasaran secara online dilakukan melalui bantuan pihak lain. Hal inilah yang menjadi pendorong untuk kegiatan pemasaran dengan melalui webset. Namun bagi UMKM yang belum pernah melakukan pemasaran online disebabkan oleh pengetahuan UMKM yang masih rendah terkait dengan keberadaan teknologi informasi.

Hasil pengolahan data yang diperoleh dari survey lapangan menunjukan bahwa tanggapan UMKM terhadap kebutuhan teknologi informasi. Dari 100 UMKM yang telah diwawancarai dan mengisi kuesioner menunjukan 75 UMKM (75\%) teknologi informasi sangat dibutuhkan. Sedangkan sisanya sebanyak 25 UMKM (25\%) menulis teknologi informasi tidak diperlukan. Dengan demikian maka kebutuhan akan teknologi informasi sangat diperlukan oleh UMKM di Jepara. Hasil wawancara terhadap 100 UMKM menyatakan bahwa teknologi informasi belum perlu dikarenakan keterbatasan pengetahuan tentang pentingnya teknologi informasi saat ini. Oleh karena itu penelitian ini diharapkan akan mampu mendorong UMKM paham tentang manfaat teknologi bagi kegiatan usaha atau bisnis.

\section{Analisis Situasi Pemasaran UMKM di Jepara}

Berdasarkan hasil analisis yang telah dilakukan oleh tim peneliti melalui Focus Grup Discution ataupun melalui penyebaran kuesioner dengan UMKM di Jepara menunjukan bahawa informasi yang berkaitan faktor lingkungan makro (ekonomi, teknologi, sosial budaya, kebijakan pemerintah dan demografi) kurang mendapat perhatian para UMKM di Jepara. Dari data yang telah diperoleh menunjukan UMKM hanya 55\% yang secara umum belum memperhatikan informasi tentang lingkungan pemasaran makro, yang berarti bahwa UMKM di Jepara belum sepenuhnya berorientasi pada peluang dan ancaman. Oleh karena itu diperlukan perhatian dari semua pihak untuk peduli terhadap kemajuan UMKM di Jepara antara lain, peneliti/perguruan tinggi, pemerintah daerah dan pihak swasta yang lain.

Namun demikian disisi lain menunjukan bahwa 45\% UMKM di Jepara telah memperhatikan perubahan lingkungan makro, yang berarti bahwa UMKM di Jepara telah mampu melihat peluang dan ancaman yang akan timbul. Berkaitan dengan hal tersebut diharapkan para UMKM di Jepara dalam menyusun strategi pemasaran yang handal perlu kiranya memperhatikan perubahan lingkungan makro yaitu perubahan teknologi. Dengan teknologi UMKM dapat menjangkau pasar yang lebih luas dan dapat melihat peluang pemasaran yang ada.
Teknologi dapat mempermudah semua urusan bisnis.

Kekuatan-kekuatan lingkungan makro tidak berpengaruh secara langsung terhadap keputusan pemasaran UMKM di Jepara. Keputusan pemasaran UMKM di Jepara sangat dipengaruhi oleh faktor lingkungan mikro seperti pemasok, pesaing, pedagang perantara, publik dan pelanggan.

\section{Model Strategi Pemasaran Berbasis Teknologi Informasi}

Dalam upaya meningkatkan daya saing UMKM di Jepara akan dicoba membuat rancangan model strategi pemasaran berbasis Teknologi Informasi. Perumusan model diawali dengan mengenali kebutuhan teknologi informasi bagi UMKM. Hasil analisis yang telah dilakukan menunjukan strategi pemasaran berbasis teknologi informasi sangat dibutuhkan. Pengenalan pemasaran melalui internet dapat memberikan kemudahan kepada pelaku UMKM untuk memasarkan produknya. Hal ini disebabkan karena : 1). dapat diakses oleh konsumen selama 24 jam, 2) dapat menjangkau pasar yang lebih luas, 3) dapat meningkatkan image UMKM, 4) mengurangi biaya pemasaran, 5) memudahkan UMKM untuk menjalin hubungan dengan konsumen,

Model strategi pemasaran berbasis teknologi informasi ini diharapkan akan mampu menyelesaikan permasalahan UMKM di Jepara terutama untuk akses pasar. Model penelitian yang digunakan terfokus pada upaya meningkatkan daya saing UMKM dengan menerapkan model strategi pemasaran berbasis teknologi informasi. Perumusan model strategi pemasaran diawali dengan mengetahui karakteristik UMKM dengan melihat aspek mikro dan aspek makro untuk merumuskan strategi pemasaran. Model strategi pemasaran berbasis teknologi informasi dalam penelitian ini dapat diilustrasikan pada gambar berikut:

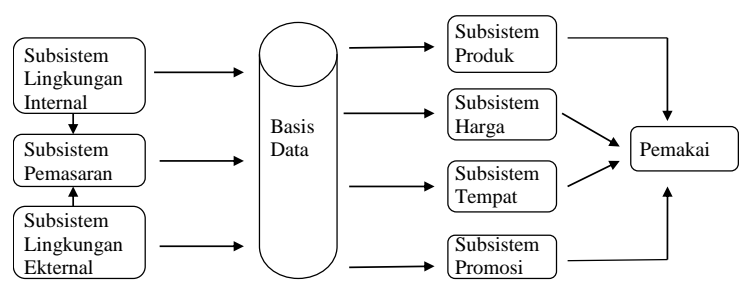

Gambar 1. Model Strategi pemasaran berbasis Teknologi Informasi sebagai upaya meningkatkan daya saing $U M K M$

Dari gambar tersebut dapat dijelaskan bahwa untuk merumuskan model strategi pemasaran berbasis teknologi diperlukan analisis terhadap 
faktor lingkungan internal dan lingkungan ekternal yang mempengaruhi pemasaran. Faktor lingkungan internal memberikan informasi mengenai keberadan atau profil UMKM, dimana akan memberikan masukan untuk subsistem pemasaran. Informasi informasi tersebut akan dimasukan kedalam data base untuk diolah. Hasil pengolahan tersebut berupa output yang berupa subsistem produk, subsistem harga, subsistem tempat dan subsistem promosi yang dipakai oleh UMKM.

Analisis terhadap lingkungan eksternal dipakai untuk melihat keberadaan para pesaing dan pelanggan. Lingkungan ini juga memberikan masukan untuk subsistem pemasaran, kemudian semua informasi yang diperoleh dari analisis lingkungan ekternal tersebut juga dimasukan ke dalam data base. Hasil pengolahan data base juga berupa output yang nantinya dapat dilihat oleh pengguna dalam hal ini bisa pelangan, pesaing dan lain sebagainya. Semua olahan data tersebut akan dimasukan dalam sebuat webset yang dapat dilihat oleh semua pihak yang memerlukan.

\section{PENUTUP}

\section{Kesimpulan}

Usaha Mikro Kecil dan Menengah merupakan salah satu inti persaingan yang fleksibel di pasar internasional. Namun sampai saat ini masih banyak permasalahan yang dihadapi oleh UMKM di Jepara diantaranya yaitu akses pasar. Untuk menjangkau pasar yang lebih luas diperlukan strategi pemasaran dan keterlibatan pihak-pihak terkait seperti pemerintah daerah, peneliti dan konsultan.

Melalui model strategi pemasaran berbasis teknologi ini pelaku UMKM di Jepara akan memperoleh berbagai informasi yang berkaitan dengan produk ataupun jejaring yang berhubungan dengan produk yang dipasarkan. Hal ini merupakan dorongan yang kondusif bagi perkembangan, kemandirian pelaku UMKM di Jepara terutama pengembangan kompetensi kreatifitas, konsistensi dan komitmennya terhadap usahanya sendiri maupun pihak lain sehingga dapat meningkatkan daya saing.

Berdasarkan analisis deskriptif bahwa UMKM di Jepara terdorong untuk menggunakan teknologi informasi yaitu untuk mengakses pasar global, mempromosikan produk, membangun merek, mendekatkan dengan pelanggan, membantu komunikasi lebih cepat dengan pelanggan dan memuaskan pelanggan. Oleh karena itu keberadaan analisis lingkungan makro informasi, terutama ekonomi dan Teknologi memiliki peran yang sangat penting dalam merumuskan strategi pemasaran UMKM. Sehubungan dengan ketentuan ini informasi mutlak yang dibutuhkan oleh UMKM maka strategi pemasaran yang mencakup strategi pasar, strategi bauran pemasaran harus ditanggapi dengan serius. Disamping hal tersebut model strategi pemasaran berbasis teknologi informasi harus diintegrasikan dengan agen web.

Saran

1. Informasi lingkungan makro khususnya ekonomi dan teknologi memiliki peran yang sangat penting dalam merusmuskan strategi pemasaran UMKM. Berkaitan dengan hal tersebut penyediaan informasi menjadi mutlak dibutuhkan oleh UMKM.

2. Strategi pemasaran yang mencakup strategi pasar, strategi bauran pemasaran harus ditangani secara serius.

3. Model Strategi pemasaran berbasis teknologi informasi sebaiknya diintegrasikan dengan web instansi terkait.

\section{REFERENSI}

Bijmolt, T and P.S. Zwart, 2004. "The Impact of Internal Factor on Export Succes of Dutch, Small and Medium Sozed Firm" Journal of Small Bussines Management 222-238

Craven, David W and Nigel F. Piercy, 2007. Strategic Marketing, McGraw- Hill, Boton

Ghosh, R., Constructing Identities, 2008, The SouthAsian Experience in North America, The Journal of Woment Studies 3 hal 127-148

Hitt, Michael A. :R Duane Ircland and Robert E, Hoskisson, 2009. Manajemen Strategi Menyongsong Era Persaingan dan Globalisasi, Cetakan kelima, Jakarta, Erlangga.

Hill R. And Walden L. 2005. The Draft Uncitral Model Low for Electronic Commerce Issue and Solution (Teaching Materials, URL http, wwwbussines fortunicity.com.

Jogiyanto, 2004. Sistim Teknologi Informasi, Penerbit Andi Ofset, Yogyakarta.

Kotler, Philip,and Garry Amstrong 2006, "Principles of Marketing” Mellinium Edition, A. Somon \& Schucer Company Ebnglewood

Kotler, Philip, 2004, Marketing Management, Milenium Edition, Prentice- Hall

Kuncoro, Mudrajat, 2006, "Strategi, Bagaimanan Meraih Keunggulan Kompetitive”, Airlangga, Jakarta. 
Lofian Budi dan Sisno Riyoko, 2013. Identifikasi Faktor Ekternal dan Faktor Internal yang berpengaruh terhadap Kinerja UKM Mebel Rotan di Jepara, "Jurnal Disprotek UNISNU hal 8-15

Martin, E. And Brown, C., 2007. Managing Information Technology, What Manager Need to Know, Singapore Prentice Hall.

Porter, Michael E, 1996. "The Competitive Strategy”, the Free Press.

Porter, Michael. E., 2006. "The Competitive Advantage of Nation” the free the Thirt, Evenue, New York.

Riyoko, Sisno, 2009. Identifikasi Faktor Penentu Pertumbuhan Industri Tenun Troso di Jepara, penelitian tidak dipublikasikan.

Tambun, Tulus, Tahi, 2006. Development of small Scale Industries during the New Order Goverent in Indonesia, Aldershot Ashagate.

Tajuddin. M, Abdul Manan, Ahmad Adil, 2011. Studi Kasus Model Strategi Pemasaran Terintegrasi berbasis Teknologi Informasi di Nusa Tenggara Barat, "Jurnal Kursor p. 68-76. 